\title{
Relationships between tail-flicking, morphology, and body condition in Moorhens
}

\author{
Fernando Alvarez, ${ }^{1,3}$ Cristina Sánchez, ${ }^{2}$ and Santiago Angulo ${ }^{2}$ \\ ${ }^{1}$ Estación Biológica de Doñana, CSIC, Apartado postal 1056, E-41080 Sevilla, Spain \\ ${ }^{2}$ Hospital Universitario Virgen Macarena, Departamento de Bioquímica Clínica, \\ Calle Doctor Fedriani s/n, Sevilla, Spain
}

\begin{abstract}
Prey-predator communication of alertness has been reported for Moorhens (Gallinula chloropus) and other species of birds. Because ability to flee is probably related to body condition, healthy potential prey may behave more conspicuously to send predators an unambiguous message. Moorhens have a contrasting rump patch that is flashed by rapid tail-flicking. During two winter months, we observed sex-related differences in the rate of tail-flicking. Females tail-flicked at a faster rate than males, and more vigilant and more symmetrical males tail-flicked faster. The rate of tail-flicking was negatively correlated to the heterophil/lymphocyte ratio in both sexes and positively correlated to hematocrit and albumin/globulin ratio in females. These results suggest that male and female Moorhens in better physical condition tail-flick at a faster rate and support the pursuit deterrent hypothesis, with healthy individuals appearing to inform predators that they would be difficult to capture.
\end{abstract}

SINOPSIS. Relació n entre la tasa de exhibición del escudo anal y la condición física en la Gallineta Gallinula chloropus

Es conocida la comunicación del estado de alerta de las presas hacia los predadores potenciales en la Gallineta Gallinula chloropus y en otras especies de aves. Puesto que la facilidad de captura está probablemente relacionada con la condición física, sería de esperar que los individuos presa en mejor condición física actuaran de forma más conspicua, pudiendo así informar sin ambigüedad a los predadores. La Gallineta presenta un escudo anal contrastado, que se hace más conspicuo mediante rápidos movimientos verticales de la cola. Durante dos meses invernales se registraron las diferencias en la tasa de movimiento de cola con relación al sexo de los sujetos, así como su relación con la tasa de vigilancia y con varios parámetros de condición física. Las hembras presentaron mayor tasa de exhibición del escudo anal que los machos, y los más vigilantes y más simétricos de éstos realizaron una exhibición más rápida. Mientras que en ambos sexos la tasa de exhibición apareció relacionada negativamente con la razón heterófilos/linfocitos, en las hembras se mostró positivamente relacionada con su hematocrito y con la razón albúmina/globulina. Estos resultados sugieren que los machos y hembras con mejor salud, así como los machos con tarsos más simétricos, realizan una más rápida exhibición, lo que apoya la hipótesis del efecto disuasorio a la persecución, ya que las presas potenciales podrían estar informando a los predadores respecto a la dificultad de su captura.

Key words: body condition, body size, fluctuating asymmetry, Gallinula chloropus, prey-predator communication, vigilance

Honest communication of alertness by prey to predators as a means of deterring attack has been reported for Eastern Swamphens (Porphyrio porphyrio), Klipspringers (Oreotragus oreotragus), and Moorhens (Gallinula chloropus) (Woodland et al. 1980, Tilson and Norton 1981, Alvarez 1993). Moorhens have a strongly contrasting rump patch that is flashed by rapid up and down tail-flicking (Wood 1974). The rate of tail-flicking increases as the risk of predation increases and appears to signal detection of the predator and the prey's state of awareness rather than being directed toward conspecifics

\footnotetext{
${ }^{3}$ Corresponding author. Email: alvarez@ebd.csic.es
}

(Alvarez 1993). Honest signaling of vigilance by Moorhens may be of mutual benefit to predators and the signaller because both would be spared an unnecessary chase. According to the handicap hypothesis (Zahavi 1975), honest signals must be costly because, if not, individuals could cheat. For Moorhens, tail-flicking could represent an honest signal if energetic costs limited such behavior to individuals in better physical condition.

Various morphological traits have been used as measures of condition (Blem 1990, Norris and Evans 2000). For example, body size is an important factor of each species' biology (Clark 1979, Kooijman 1986) and fluctuating asymmetry appears to be a valid indicator of 
environmental and genetic stress (Leary and Allendorf 1989, Parsons 1992, Swaddle and Witter 1994, Yang et al. 1997). Blood composition may also be a good indicator of condition (Brown 1996). The hematocrit (or packed cell volume, PCV) has been considered an index of metabolic activity and fitness in wild birds (Carpenter 1975, Birchard 1997, Ots et al. 1998) and high PCV values are associated with increased workloads (Saino et al. 1997, Hõrak et al. 1998, Alvarez and Sánchez 2003) and better physical condition (Merilä and Svensson 1995, Svensson and Merilä 1996, Wanless et al. 1997). Low hematocrit values may indicate anemia, and abnormally high values may indicate disease or dehydration (Nelsen and Brandl 1988, Campbell 1995, Ots et al. 1998). In general, however, more vigorous individuals have higher hematocrits.

Because of the association of leukocytes with disease and stress, higher leukocyte numbers are regarded as an indicator of poor condition (Brown 1996). Leukocytosis is often associated with macroparasites, blood parasites, bacterial, fungal and viral infections, traumatic injury, hemorrhage, toxicities, neoplasm, and leukemia (Fudge 1989, Gustafsson et al. 1994, Campbell 1995). Therefore, at least with the exception of leukopenia, which may be the result of severe malnutrition, strenuous exercise, or significant weight loss (Owen and Sogge 2002), diseased individuals would tend to have high leukocyte counts.

Among the different types of leukocytes, heterophils are nonspecific and highly phagocytic, with a broad spectrum of antimicrobial activity, and form part of the first line of cellular defense against antigenic challenge. Lymphocytes are highly specific immune cells, and play a role in the recognition and destruction of many pathogens (Siegel 1985, Harmon 1998, Ots et al. 1998). The ratio of heterophils to lymphocytes $(\mathrm{H} / \mathrm{L})$ is widely used as an index of chronic stress and is known to increase in response to various stressors, including infectious diseases, parasitemia, high workload, food or water deprivation, psychological stress, extreme temperatures and injury, with its effects depending on the duration and form of the stress (Gross and Siegel 1983, Maxwell 1993, Hõrak et al. 1998, Work et al. 1999, Vleck et al. 2000, Owen and Sogge 2002). Although more heterophils would seem to enhance resistance to infection, their accumulation and lysis in inflamed tissue may cause tissue damage (Harmon 1998). As a result, animals in poor condition have higher $\mathrm{H} / \mathrm{L}$ ratios.

Albumin is the most abundant plasma protein. Due to its function as a carrier of metabolites in protein synthesis and as an energy source, a decrease in albumin concentration is a symptom of almost all pathological states (particularly malnutrition, liver disorders, and inflammation). The globulin fraction of plasma proteins is especially important following injury. This includes immunoglobulins (Ig), which play an important role in recognizing and binding antigens. An increased Ig concentration occurs in response to antigenic stimulation (by protozoa, bacteria, and viral infections). Diseased individuals suffering from chronic or inflammatory diseases exhibit a lower albumin/globulin (Alb/Glo) ratio than healthy individuals (Kawai 1973, Lumeij and Overduin 1990).

Our objective was to determine if the rate of tail-flicking by Moorhens was related to various vigilance, developmental, and body condition indices. Such relationships, even if significant, would not provide a direct test of the hypothesis that prey, for example, Moorhens, in superior physical condition signal predators concerning their ability to escape. However, our goal was to test one of the assumptions of the hypothesis, namely that conspicuous tail-flicking behavior reflects individual differences in physiological condition. To that end, we examined possible correlations between the rate of tail-flicking and tarsus asymmetry, fat indices, hematocrit values, leukocyte indices, heterophil/lymphocyte ratios, and albumin/globulin ratios.

\section{METHODS}

This study was conducted at La Lantejuela (southwest Spain, $37^{\circ} 21^{t} \mathrm{~N}, 5^{\circ} 13^{t} \mathrm{~W}$ ) during January and February 2003. Moorhens were trapped and observed along five adjacent freshwater pools that provided habitat for Moorhens as well as several avian predators, including Marsh Harriers (Circus aeruginosus), Buzzards (Buteo buteo), and Peregrine Falcons (Falco peregrinus). We captured Moorhens in funnel wire traps baited with barley and each was individually marked with a metal band and a numbered neck collar. They were also weighed ( $\pm 1 \mathrm{~g})$ and both tarsi were measured with a digital 
caliper ( $\pm 0.01 \mathrm{~mm})$. Tarsus length was used as a measure of body size and body mass $x$ tarsus length $^{-3}$ was used as an index of fat reserves

(Petrie 1983). Measurements were taken twice, and always by the same person. Asymmetry in tarsus length was defined as the difference in length of the two tarsi (Palmer 1994). The two values obtained for these measures were used to calculate the mean values used in the calculations and the repeatability correlation coefficients.

Blood samples (about $1.5 \mathrm{ml}$ total) were taken from a vein in the leg of each Moorhen. Blood collected in two capillary tubes was used to determine hematocrit values, and two blood smears were used for leukocyte and blood parasite counts. Two drops of blood were used for sex determination, and the rest was used for plasma protein assays. Capillary tubes were kept on ice for 3-4 h, then centrifuged for $8 \mathrm{~min}$ at $11,500 \mathrm{rpm}$ in a portable centrifuge (M 1101, Bayer Diagnostics, München, Germany). Hematocrits were then calculated by measuring the capillary tubes (blood cell length/total length of blood cells plus plasma). The hematocrit for each bird was determined by averaging the two samples.

Blood smears were obtained by collecting a drop of blood in a microcapillary tube, and transferring it to a clean air-dried glass slide fixed in absolute methanol for $10 \mathrm{~min}$. Slides were stained following the May Grünwald-Giemsa technique. Leukocytes and blood parasites were counted by an experienced laboratory technician on 100 fields under oil, using a magnification of $100 \times$. No blood parasites were found in the samples. A leukocyte index was obtained by multiplying each subject's leukocyte count by its observed PCV (Campbell 1995), and the ratio of heterophil/lymphocyte $(\mathrm{H} / \mathrm{L})$ counts was also determined. One-third of all samples were examined twice to assess repeatability.

Sex was determined from blood samples (two drops of blood preserved in absolute ethanol at ambient temperature) using polymerase chain reaction (PCR) amplification of CHD1 genes with primers P2 and P8 (Griffiths et al. 1998). Females were unambiguously identified by the amplification of two PCR products of 380 and 340 base pairs, corresponding to the CHD1-Z and CHD1-W genes, respectively, while males yielded only the longer fragment.

Plasma samples for protein electrophoresis were obtained after centrifugation of blood at
$4000 \mathrm{rpm}$ for $5 \mathrm{~min}$ (with vials contained gel helping to separate plasma from clots) and then stored at $4^{\circ} \mathrm{C}$. The relative abundance of albumin and immunoglobulins (alpha-, beta- and gamma-globulins) (Alb/Glo ratio, expressed as the ratio between the areas in the densitometric profile) was obtained with values provided by the Parangon CZE 2000 instrument (Beckman Coulter Inc., Fullerton, CA, USA), through capillary-zone electrophoresis. To assess repeatability, two samples were obtained from about one-third of the birds.

Within nine days of capture, adult male $(N=$ $21)$ and female $(N=27)$ Moorhens were observed for at least four days from 08:00 to 11:00. During observations, Moorhens searched for food while walking alone, no more than $10 \mathrm{~m}$ from cover, with no conspecifics or predators in view. From the top of a 6-m high observation stand providing a view of all five pools, an observer (F.A.) equipped with a 40-60× telescope and hand counter noted the identity of the focal Moorhen and, for 15 min each day, recorded, beginning when the bird was first observed, each upward movement of the tail (or tail-flick) and the number of times it was vigilant (remaining motionless with its neck stretched up, sometimes tilting its head to look at the sky with one eye). Only data collected from Moorhens observed for at least four days (range $=4-6 \mathrm{~d}$ ) were used in subsequent analyses.

Because tail-flicking rates deviated significantly from a normal distribution $(P<0.01$, Kolmogorov-Smirnov test), nonparametric tests were used. The Mann-Whitney $U$-test was used to compare tail-flicking rates of males and females. The relationship between rate of tailflicking and parameters of body condition was examined using Spearman rank correlation and sequential Bonferroni tests (Siegel and Castellan 1988, Sokal and Rohlf 1995). The repeatability of the doubly recorded variables (tarsus length, tarsus asymmetry, body weight $\times$ tarsus length $^{-3}$, hematocrit, leukocyte index, and H/L and Alb/Glo ratios) was high (coefficient of intraclass correlation: $0.81<r_{1}<0.98,13<$ df $<65, P<0.001$; Zar 1996).

\section{RESULTS}

Female Moorhens tail-flicked at a faster rate $(\overline{\mathrm{x}}=21.30 \pm 9.96(\mathrm{SD})$ per $\min ; N=27)$ 
Table 1. Correlations between the rate of tail-flicking by male and female Moorhens and various indices of vigilance, developmental, and body condition during the winter at La Lantejuela, Spain.

\begin{tabular}{lrrrr}
\hline & \multicolumn{2}{c}{ Females } & \multicolumn{2}{c}{ Males } \\
\cline { 2 - 5 } Variables & $r_{s}$ & $N$ & $r_{s}$ & $N$ \\
\hline Vigilance rate & 0.36 & 27 & $0.63^{*}$ & 21 \\
Body size & -0.16 & 27 & 0.19 & 21 \\
Tarsus asymmetry & -0.39 & 27 & $-0.61^{*}$ & 21 \\
Fat index & 0.42 & 27 & -0.03 & 21 \\
Hematocrit & $0.54^{*}$ & 27 & -0.43 & 18 \\
Leukocyte index & 0.27 & 24 & -0.03 & 18 \\
H/L ratio & $-0.54^{*}$ & 24 & $-0.61^{*}$ & 18 \\
Alb/Glo ratio & $0.68^{*}$ & 22 & 0.21 & 16 \\
\hline
\end{tabular}

${ }^{*}$ Significant at $P<0.05$ after a sequential Bonferroni correction for multiple comparisons (calculated separately for each sex).

than males $(\overline{\mathrm{x}}=9.61 \pm 7.23$ per $\min , N=$ 21; $P<0.001$; Mann-Whitney $U$ test). The correlations of the rate of tail-flicking with the rate of vigilance and the parameters of body condition are provided in Table 1 . Tail-flicking was positively related to the rate of vigilance in both sexes, although the relationship was significant only for males.

Concerning body dimensions (body size and tarsus asymmetry), the only significant correlation was a negative one between tail-flicking rate and tarsus asymmetry for males (those with more symmetrical tarsi tail-flicked faster; Fig. 1). With respect to the other indices of condition, tailflicking was negatively related to the $\mathrm{H} / \mathrm{L}$ ratio in both sexes (i.e., males and females that were healthier in this respect tail-flicked faster). For females, significant positive correlations were also

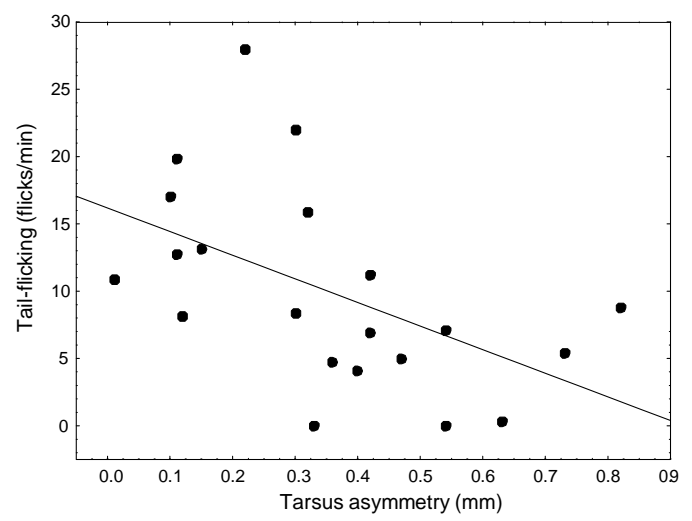

Fig. 1. Rate of tail-flicking relative to tarsus asymmetry for male Moorhens (linear fit shown). found for the Alb/Glo ratio (females healthier in this respect tail-flicked faster) and the hematocrit (females with more efficient oxygen transfer tailflicked faster; Table 1).

\section{DISCUSSION}

The positive relationship between the tailflicking rate and the rate of vigilance supports the idea that Moorhens may be communicating their state of awareness to potential predators (Alvarez 1993). However, the significant correlation between the tail-flicking rate and several measures of body condition also suggests that Moorhens provide information about their physical condition.

Moorhens run for cover or shelter when fleeing from predators, and we found that male Moorhens with more symmetrical tarsi tailflicked at a faster rate. This may provide support for the hypothesis that Moorhens communicate their ability to flee, providing it can be demonstrated that bilateral symmetry affects running speed (e.g., racehorses; Manning and Ockenden 1994). However, the relationship between the rate of tail-flicking and the degree of symmetry of tarsi was significant only for males and, in addition, body symmetry may signal high levels of developmental stability (Møller and Swaddle 1997) rather than speed of locomotion.

The negative correlation between tail-flicking rate and the $\mathrm{H} / \mathrm{L}$ ratio for both male and female Moorhens plus the positive correlation between tail-flicking rate and the Alb/Glo ratio in females suggest that birds in better condition tail-flick at higher rates. In addition, 
because higher hematocrits represent a common physiological response to prolonged muscular activity (Carpenter 1975, Brown 1996, Wanless et al. 1997), the positive correlation between hematocrit values and rate of tail-flicking in female Moorhens suggests that tail-flicking at higher rates increases the demand for oxygen by the tail muscles. Collectively, these results are consistent with the hypothesis that tail-flicking in Moorhens serves as an honest indicator of overall physiological condition.

Honest signaling of an individual's ability to flee from predators by rapid tail-flicking, although apparently requiring energy, may over the long term actually reduce energy needs because such signaling may mean fewer attacks and, therefore, less time and energy expended in escaping from attacking predators. Such signaling would presumably be of mutual benefit to both the signaler and the predator (enabling the latter not to waste time and energy on an attack likely to be unsuccessful). On the other hand, less able individuals (slow runners or individuals in poor condition) would not run the risk of increasing their already greater vulnerability by attracting the predators' attention by tail-flicking.

Moorhens do not appear to tail-flick toward conspecifics. In our study, they were observed while foraging alone with no conspecifics in view and, in a previous study (Alvarez 1993), Moorhens foraging in loose groups typically directed their tail-flicks away from conspecifics. Nevertheless, the possibility of signaling health status to conspecifics should not be dismissed, particularly because our study was conducted just prior to the breeding season and females, who play a more active role in pair formation than males (Petrie 1983), were found to tail-flick at faster rates than males.

\section{ACKNOWLEDGMENTS}

We thank E. Aguilera, J.A. Amat, J.A. Godoy, M. Vázquez, and M. Vega for help with various aspects of the study. Funding was provided by the Department of Education and Science of Spain (BOS2001-0541, CGL200400772).

\section{LITERATURE CITED}

Alvarez, F. 1993. Alertness signaling in two rail species. Animal Behaviour 46: 1229-1231.

Alvarez, F., AND C. SÁnchez. 2003. The features of distraction behaviour and their relationship with physical condition in Rufous Bush Chats. Ethology Ecology and Evolution 15: 355-368.

BIRCHARD, G. F. 1997. Optimal hematocrit: theory, regulation and implications. American Zoologist 37: 6572.

Blem, C. R. 1990. Avian energy storage. Current Ornithology 7: 59-113.

Brown, M. E. 1996. Assessing body condition in birds. Current Ornithology 13: 67-135.

CampBell, T. W. 1995. Avian hematology and cytology. Iowa State University Press, Ames, IA.

CARPENTER, F. L. 1975. Bird hematocrits: effect of high altitude and strength of flight. Comparative Biochemistry and Physiology A 50: 415-417.

CLARK, F. A. 1979. Body weight of birds: a review. Condor 81: 193-202.

FudGE, A. M. 1989. Avian hematology: identification and interpretation. Proceedings of the Association of Avian Veterinarians Annual Meeting, pp. 284-292.

Griffiths, R., M. C. Double, K. ORR, AND R. J. G. DAWSON. 1998. A DNA test to sex most birds. Molecular Ecology 7: 1071-1075.

Gross, W. B., AND H. S. SIEGEL. 1983. Evaluation of the heterophil-lymphocyte ratio as a measure of stress in chickens. Avian Diseases 27: 972-979.

Gustafsson, L., D. Nordling, M. S. Andersson, B. C. SHELDON, AND A. QVARNSTRÖM. 1994. Infectious diseases, reproductive effort and the cost of reproduction in birds. Philosophical Transactions of the Royal Society of London B 346: 323-331.

Harmon, B. G. 1998. Avian heterophils in inflammation and disease resistance. Poultry Science 77: 972-977.

Hõ RAK, P., I. OTS, AND A. MuRUMÄGI. 1998. Haematological health state indices of reproducing Great Tits: a response to brood size manipulation. Functional Ecology 12: 750-756.

KAWAI, T. 1973. Clinical aspects of the plasma proteins. Igaku Shoin, Tokyo, Japan.

KoolJMAN, S. A. L. M. 1986. Energy budgets can explain body size relations. Journal of Theoretical Biology 121: 269-282.

LEARY, R. L., AND F. W. AlLENDORF. 1989. Fluctuating asymmetry as an indicator of stress: implications for conservation biology. Trends in Ecology and Evolution 4: 214-217.

LumeiJ, J. T., AND L. M. Overduin. 1990. Plasma chemistry reference values in Psittaciformes. Avian Pathology 19: 235-244.

MANNING, J. T., AND L. OCKENDEN. 1994. Fluctuating asymmetry in racehorses. Nature 370: 185-186.

Maxwell, M. H. 1993. Avian blood leukocyte responses to stress. World's Poultry Science Journal 49: 34-43.

Merilä, J., AND E. Svensson. 1995. Fat reserves and health state in migrant Goldcrest Regulus regulus. Functional Ecology 9: 842-848.

Møller, A. P., AND J. P. SwADDLE. 1997. Asymmetry, developmental stability, and evolution. Oxford University Press, Oxford, UK.

NELSEN, I., AND R. BRANDL. 1988. Plasma glucose and haematocrit of young Black-headed Gulls Larus ridibundus. Journal of Zoology, London 215: 183-187.

Norris, K., AND M. R. EvANS. 2000. Ecological immunology: life history trade-offs and immune defense in birds. Behavioral Ecology 11: 19-26. 
Ots, I., A. Murumägi, AND P. Hõ RAK. 1998. Haematological health state indices of reproducing Great Tits: methodology and sources of natural variation. Functional Ecology 12: 700-707.

Owen, J. C., AND M. K. Sogge. 2002. Physiological condition of southwestern Willow Flycatchers in native and saltcedar habitats. U. S. Geological Survey report to the Arizona Department of Transportation, Phoenix, AZ.

PAlmer, A. R. 1994. Fluctuating asymmetry analyses: a primer. In: Developmental instability: its origins and evolutionary implications (T. A. Markow, ed.), pp. 335-364. Kluwer, Dordrecht, The Netherlands.

PARSONS, P. A. 1992. Fluctuating asymmetry: a biological monitor of environmental and genomic stress. Heredity 68: 361-364.

Petrie, M. 1983. Female Moorhens compete for small fat males. Science 220: 413-415.

Saino, N., J. J. Cuervo, M. KrivaceK, F. DE Lope, AND A. P. MøLLER. 1997. Experimental manipulation of tail ornament size affects the hematocrit of male Barn Swallows (Hirundo rustica). Oecologia 110: 186190.

SIEGEL, H. S. 1985. Immunological responses as indicators of stress. World's Poultry Science Journal 41: 3644.

SiEgEl, S., AND N. J. CASTELLAN. 1988. Nonparametric statistics for the behavioral sciences. McGraw-Hill, New York, NY.

SoKal, R. R., AND F. J. Rohlf. 1995. Biometry. W. H. Freeman, New York, NY.

SVEnSSON, E., AND J. MERILÄ. 1996. Molt and migratory condition in Blue Tits: a serological study. Condor 98: 825-831.
Swaddle, J. P., AND M. WitTER. 1994. Food, feathers and fluctuating asymmetries. Proceedings of the Royal Society of London B 255: 147-152.

Tilson, R. L., AND P. M. NoRTon. 1981. Alarm duetting and pursuit deterrence in an African antelope. American Naturalist 118: 455-462.

VleCK, C. M., N. Vertalino, D. VleCK, AND T. Bucher. 2000. Stress, corticosterone, and heterophil to lymphocyte ratios in free-living Adélie Penguins. Condor 102: 392-400.

WANLESS, S., T. R. BARTON, AND M. HaRris. 1997. Blood hematocrit measurements of four species of North Atlantic seabirds in relation to levels of infestation by the tick Ixodes uriae. Colonial Waterbirds 20: 540544.

Wood, N. A. 1974. The breeding behaviour and biology of the Moorhen. British Birds 67: 104-115, 137158.

WoOdLAND, D. J., Z. JAAFAR, AND M. L. KNIGHT. 1980. The "pursuit deterrent" function of alarm signals. American Naturalist 115: 748-753.

Work, T. M., J. G. MASSEY, L. Johnson, S. DougILL, AND P. C. BANKo. 1999. Survival and physiologic response of Common Amakihi and Japanese Whiteeyes during simulated translocation. Condor 101: 21-27.

Yang, A., E. A. Dunnington, And P. B. Siegel. 1997. Developmental stability in stocks of white leghorn chickens. Poultry Science 76: 1632-1636.

ZaHAVI, A. 1975. Mate selection - a selection for a handicap. Journal of Theoretical Biology 53: 205214.

ZAR, J. H. 1996. Biostatistical analysis. Prentice Hall, Upper Saddle River, NJ. 